Jurnal Konstruksi Hukum | ISSN: 2746-5055

Vol. 2, No. 1, Januari $2021 \mathrm{Hal}$. 97-101| Tersedia online di https://www.ejournal.warmadewa.ac.id/index.php/jukonhum DOI: https://10.22225/jkh.2.1.2976.97-101

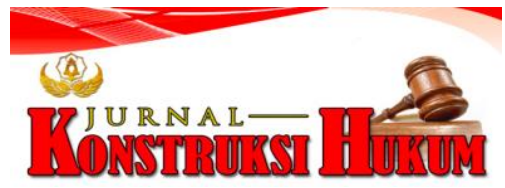

\title{
TANGGUNG JAWAB HUKUM TERHADAP ADANYA WANPRESTASI DALAM PERJANJIAN SEWA MENYEWA RUMAH TOKO (RUKO)
}

\author{
I Made Sukayasa, I Nyoman Putu Budiartha, Luh Putu Suryani \\ Fakultas Hukum Universitas Warmadewa, Denpasar-Bali, Indonesia
}

\begin{abstract}
Abstrak
Persaingan ekonomi menjadi prioritas bagi pelaku usaha diberbagai daerah dan kota, sehingga banyak melakukan pembaharuan bangunan dengan dibangunnya ruko-ruko. Sistem perekonomian yang semakin berkembang maka ruko-ruko yang telah dibangun dapat dijadikan sebagai sarana dalam jual beli. Ruko sering dikenal dengan sebutan rumah toko atau tempat tinggal yang dijadikan sekaligus tempat usaha dan biasanya ruko ini dibangun sejajar dengan bangunan ruko lainnya. Penelitian ini bertujuan untuk mendeskripsikan kepastian dari perjanjian sewa menyewa Rumah Toko dan menjelaskan tanggung jawab hukum apabila salah satu pihak melakukan wanprestasi dalam pelaksanaan perjanjian sewa menyewa Rumah Toko. Penelitian didesain menggunakan hukum normatif adalah hukum kepustakaan yang mengacu pada norma hukum yang terdapat dalam peraturan Perundang-undangan. Pendekatan perundangan-undangan adalah melakukan suatu penelitian dengan berpatokan pada undang-undang sebagai dasar dalam penelitian ini, adapun sumber data yang dihunakan adalah data hukum primer dan sekunder data diperoleh melalui buku-buku ilmu hukum tanpa melenceng dari hukum positif demi merangkai sebuah kesimpulan. Hasil penelitian menunjukkan bahwa Suatu kesepakatan antara penyewa dan si pemilik bangunan dapat memunculkan hak dan kewajiban antar pihak yang di tulis dalam sebuah perjanjian, hal imi telah diatur Pada KUHPer. Pihak yang menyewakan mempunyai kewajiban untuk menyerakan hak yakni bangunan yang disewakan kepada penyewa dan memiliki hak untuk mendapatkan bayaran dari penyewa atas bangunan sewa. Penyewa tidak boleh mengalihkan hak atas bangunan yang disewanya dan apabila ada sengketa dikemudian hari antara para pihak maka harus diselesaikan karena wanprestasi.
\end{abstract}

Kata kunci: Wanprestasi; Sewa Menyewa Ruko; Tanggung Jawab Hukum

\begin{abstract}
Economic competition is a priority for business actors in various regions and cities, so that many renovation of buildings are carried out with the construction of shop-houses. The economic system is increasingly developing, so the shophouses that have been built can be used as a means of buying and selling. Shophouses are often known as shop houses or residences which are used as a place of business and usually these shophouses are built parallel to other shop buildings. This study aims to describe the certainty of the Shophouses rental agreement and explain the legal responsibility if one of the parties defaults on the implementation of the Shophouses rental agreement. This research is designed to use normative law, which is literature law which refers to the legal norms contained in statutory regulations. The statutory approach is to carry out a study based on the law as the basis for this research, while the data sources used are primary and secondary legal data. Data is obtained through legal science books without deviating from positive law in order to form a conclusion. The results showed that an agreement between the tenant and the owner of the building can create rights and obligations between the parties that are written in an agreement, this has been regulated in the Criminal Code. The lessee has the obligation to assign rights, namely the building that is leased to the tenant and has the right to get payment from the tenant for the leased building. The tenant may not transfer the rights to the building he leases and if there is a dispute in the future between the parties, it must be resolved because of default.
\end{abstract}

Keywords: Default; Leasing of Shophouse, Legal Liability

\section{PENDAHULUAN}

Ruko atau yang sering disebut dengan rumah toko merupakan bangunan yang biasa dibuat dengan bertingkat minimal dua sampai lima lantai tergantung dari keinginan pemilik ruko tersebut, yang memiliki fungsi sebagai tempat tinggal maupun tempat usaha. Pada umumnya, lantai satu dijadikan tempat usaha sedangkan lantai paling atas dijadikan tempat tinggal. Ruko ini marak dibangun di berbagai kawasan kota dan daerah yang ada di Indonesia. Sistem perekonomian yang semakin berkembang maka ruko-ruko yang telah dibangun dapat dijadikan sebagai sarana dalam jual beli (Richards \& Schmidt, 2010). Ruko sering dikenal dengan sebutan rumah toko atau tempat tinggal 
yang dijadikan sekaligus tempat usaha dan biasanya ruko ini dibangun sejajar dengan bangunan ruko lainnya. Hal itu memiliki tujuan untuk masyarakat menjadi lebih mudah dalam melaksanakan kegiatan transaksi bisnisnya yang di bangun dalam sebuah konsep tertentu dan dalam satu kawasan.

Perkembangan pasar tradisional saat ini ruko juga sering dijadikan tempat untuk mencari rejeki. Adanya hal tersebut dapat mendorong pihak pemilik ruko untuk dapat memenuhi kebutuhannya ataupun dapat meningkatkan taraf kehidupannya agar menjadi lebuh baik. Selain dapat dimiliki sendiri ternyata pada masa ini ruko dapat dipindah tangankan status kepemillikan dengan adanya transaksi jual beli dan transaksi sewa menyewa. Transaksi jual beli dan transaksi sewa menyewa adalah perjanjian konsensual yang sama seperti pada perjanjian pada umumnya yang memiliki arti sebagai tanda kesepakatan maka pihak pihak yang terlibat sudah mengikatkan diri satu dan sama lainnya serta sudah sah dan memiliki dua unsur terpenting yakni dalam perjanjian sewa menyewa yang memiliki batasan waktu tertentu, karena perjanjian sewa menyewa tanpa waktu tertentu tidak diperbolehkan (Salim, 1979). Apabila ada salah satu pihak yang meninggal maka perjanian sewa menyewa tidak berpengaruh dan barang atau bangunan yang disewakan bisa dipindah tangankan ( $R$. Setiawan, 1987).

Perjanjian sewa menyewa merupakan suatu kesepakatan yang dituangkan dalam perjanjian tertulis dengan isi para pihak mengikatkan dirinya satu sama lainnya dalam waktu yang ditentukan serta memiliki nilai harga yang telah disepakati sehingga menimbulkan suatu kewajiban untuk penyewa membayarkan barang atau bangunan yang disewakannya.

Negosiasi adalah tindakan awal sebelum membuat sebuah perjanjian. Negosiasi ialah tindakan yang dilakukan oleh kedua belah pihak sebelum membuat perjanjian untuk mencapai kesepakatan dan menentukan poin-poin dalam perjanjian tersebut yang memiliki hak dan kewajiban kepada masing-masing para pihak (Saputra, Asbudi Dwi) Tahapan selanjutnya dilanjutkan dengan pembuatan Memorandum of Understanding (MoU). MoU ini adalah sebuah bentuk dokumentasi yang berdasarkan hasil negosiasi yang dilakukan dan dibuat dalam sebuah tulisan. MoU menjadi sebuah dasar dalam melakukan perjanjian kontrak dan MoU belum memiliki nilai yang standar dalam Kontrak hanya saja menjadi dasar pemikiran untuk menciptakan sebuah kontrak. Tahapan selanjutnya setelah memperoleh MoU para pihak dilanjutkan dengan teori layal tidaknya (feasibility study, due diligent) yang memiliki fungsi untuk menilai kelayakan dan kemungkinan terjadi usaha tersebut dimasa depan berdasarkan sudut pandang hukum, lingkungan, ekonomi, pemasaran, keuangan, sosial budaya, lingkungan, dan teknik. Teori kelayakan ini dibutuhkan dalam penilaian apakah transaksi para pihak patut untuk dilanjutkan. Setalah diuji maka apabila layak akan melanjutkan pada proses pembuatan perjanjian kontrak.

Penulisan kontrak harus detail dalam menuangkan pikirian-pikiran dan keingginan para pihak, berdasarkan dengan nilai hukum dan bahasa yang sah digunakan dalam sebuah perjanjian kontrak yakni dengan digunakannya bahasa yang baik dan benar sesuai dengan standar Bahasa Indonesia yang tepat, jelas dan sistematis. Perjanjian termasuk dalam kategori hukum mengenai diri pribadi dan kekayaan karena hal tersebut dipadukan antara cakapnya seseorang yang ingin melakukan perjanjian dalam bertindak dan bertanggung jawab serta dengan hal yang dapat di lihat dari nilai uang.

Pada saat ini, suatu perjanjian biasa dikenal dengan istilah kontrak, yang harus bersumber dan berdasar atas pembuatannya dengan syarat sahnya perjanjian ataupun kontrak. Harus adanya kesepakatan antara mereka yakni para pihak untuk mengikat dirinya satu sama lain dengan ditandainya adanya rasa saling memberi, ikhlas ataupun menerima antara pihak yang terkait. Kontrak yang timbul diakibatkan oleh unsur paksaan, kekhilafan maupun penipuan dapat mematahkan nilai kesepakatan. Kecakapan yang dimaksud ialah para pihak yang terkait dalam pembuatan kontrak haruslah sudah sesuai oleh peraturan di Indonesia yang berlaku yang menunjukkan dapat dijadikan sebagai subjek hukum. Pemberian jaminan kepada para pihak maka diperlukan hal ini agar tidak timbulnya perjanjian fiktif, seperti perjanjian sewa menyewa ruko maka harus jelas lokasi ruko dan rincian bentukan rukon tersebut tidak boleh hanya sewa menyewa ruko tanpa memiliki keterangan yang pasti. Syarat selanjutnya ialah suatu sebab yang halal yang dimaksudkan adalah setiap isi perjanjian yang dibuat tidak boleh menentang ataupun bertolak belakang dari peraturan yang berlaku dalam Indonesia. Seperti jual beli manusia yang tidak sah karena melanggar dan menolak dengan norma yang diatur tersebut. 
Perjanjian antara penyewa dan pemilik memiliki hak dan kewajiban antara para keduanya yaitu penyewa memiliki hak untuk mendapatkan fasilitas ruko dan memiliki kewajiban untuk membayar biaya sewa yang sudah di sepakati, sedangkan hak dan kewajiban pemilik ialah ia berhak untuk mendapatkan pembayaran dari penyewa dan pemilik memiliki kewajiban untuk menyerahkan ruko tersebut untuk dipergunakan oleh penyewa. Jika dikemudian hari terjadi ketelodoran antara salah satu pihak yang berjanji maka harus mengganti rugi dan bertanggungjawab atas wanprestasinya (Hamsah, 1986).

Menurut Slamet, (2013). Wan prestasi adalah arti dari ketidak tepatan antara para pihak untuk memenuhi isi perjanjian yang telah di sepakati sehingga menimbulkan kerugian salah satu pihak akibat dari cidera janji tersebut. Penelitian lain mengugkapkan bahwa Apabila pihak penyewa tidak melaksanakan apa yang menjadi kewajibannya maka pihak yang menyewakan dapat menuntut untuk meminta pelaksanaan perjanjian, atau meminta ganti kerugian ataupun bisa kedua-duanya yaitu meminta pelaksanaan disertai dengan ganti rugi (Kondo, 2013).

\section{METODE PENELITIAN}

Penelitian didesain menggunakan hukum normatif adalah hukum kepustakaan yang mengacu pada norma hukum yang terdapat dalam peraturan Perundang-undangan. Pendekatan perundanganundangan adalah melakukan suatu penelitian dengan berpatokan pada undang-undang sebagai dasar penulisan skripsi. Pendekatan kasus dilakukan guna melihat, mencatat dan memahami permasalahan yang diangkat dalam penelitian ini dengan tidak keluar dari zona hukum positif (Waluyo, 2002). Adapun sumber data yang dihunakan adalah data hukum primer dan sekunder. Metode penelitian yang digunakan adalah normatif dan kualitatis dimana dalam pengerjaannya menelaah isu hukum dengan didasari peraturan-peraturan hukum di Indonesia dengan menggunakan metode normatif dan kualitatis dimana dalam menelaah isu hukum dengan didasari peraturan-peraturan hukum di Indonesia (Ahmad, 2008)

\section{HASIL DAN PEMBAHASAN}

\section{Kepastian dari Perjanjian Sewa Menyewa Rumah Toko}

Pada KUHPer memiliki suatu aturan yang berlaku ada pada setiap perjanjian. Misalka perjanjian sewa menyewa, jual beli, pinjam meminjam dll. Suatu peristiwa dimana dua orang sudah sepakat untuk mengikatkan diri satu sama lain dan saling berjanji untuk melakukan poin-poin dari nilai yang disepakati. Fungsi antara perundang-undangan dengan perjanjian kontrak adala satu hal yang sama hanya saja yang membedakan dapat berlaku untuk siapa saja. Apa bila perjanjian kontrak hanya berlaku antara para pihak yang terkait dalam perjanjian kontrak adalah pembuat perjanjian kontrak tersebut sedangkan dalam perundang-undangan berlaku untuk siapa saja yang tinggal dalam kawasan yang ditentukan dalam hal ini adalah negara Indonesia. Isi semua perjanjian sama dengan perundang-undangan asalkan pembuatan atau standar perjanjian sudah memenuhi syarat. Sebagai berikut:

1. Harus adanya kesepakatan antara mereka yakni para pihak untuk mengikatnya dirinya satu sama lain dengan ditandainya adanya rasa saling memberi, ikhlas ataupun menerima antara pihak yang terkait. Kontrak yang timbul diakibatkan oleh unsur paksaan, kekhilafan maupun penipuan dapat mematahkan nilai kesepakatan.

2. Kecakapan yang dimaksud ialah para pihak yang terkait dalam pembuatan kontrak haruslah sudah sesuai oleh peraturan di Indonesia yang berlaku yang menunjukan dapat dijadikan sebagai subjek hukum. disebut kategori tidak cakap karena orang yang ditunjuk oleh hukum yakni orang dewasa tetapi dalam pengampuan, anak-anak dan orang yang tidak memiliki akal sehat seperti berumur 18 tahun dan belum pernah menikah. Selain hal yang disebutkan diatas adalah sudah dianggap cakap dalam membuat perjanjian

3. Suatu hal tertentu yang dimaksudkan dengan adanya objek yang diatur dalam perjanjian sudah jelas adanya. Karena dalam memberikan jaminan kepada para pihak maka diperlukan hal ini agar tidak timbulnya perjanjian fiktif. hal ini seperti perjanjian sewa menyewa ruko maka harus jelas lokasi ruko dan rincian bentukan rukonya tersebut, tidak boleh hanya sewa menyewa ruko tanpa memiliki keterangan yang pasti.

Suatu perjanjian dapat dikatakan sah dan berlaku secara hukum bagi para pembuatnya apabila perjanjian sudah memenuhi tiga unsur diatas. Pada perjanjian sewa menyewa pihak yang 
terikat dan terlibat adalah penyewa dan pemilik ruko. Dimana pihak yang menyewakan merupakan orang yang memiliki barang, benda atau bangunan yang ingin disewakan kepada si penyewa. Sedangkan si penyewa adalah orang yang memiliki niat untuk menyewa barang, benda atau bangunan dari si menyewakan dalam batasan barang yang di sewa tidak bertolak belakang dengan norma yang berlaku.

\section{Tanggung Jawab Hukum Melakukan Wanprestasi dalam Pelaksanaan Perjanjian Sewa Menyewa Rumah Toko}

Perjanjian sewa menyewa merupakan suatu kesepakatan yang dituangkan dalam perjanjian tertulis dengan isi para pihak mengikatkan dirinya satu sama lainnya dalam waktu yang ditentukan serta memiliki nilai harga yang telah disepakati sehingga menimbulkan suatu kewajiban untuk penyewa membayarkan barang atau bangunan yang disewakannya. Negosiasi adalah tindakan awal sebelum membuat sebuah perjanjian. Negosiasi ialah tindakan yang dilakukan oleh kedua belah pihak sebelum membuat perjanjian untuk mencapai kesepakatan dan menentukan poin-poin dalam perjanjian tersebut yang memiliki hak dan kewajiban kepada masing-masing para pihak. Tahapan selanjutnya dilanjutkan dengan pembuatan Memorandum of Understanding (MoU). MoU ini adalah sebuah bentuk dokumentasi yang berdasarkan hasil negosiasi yang dilakukan dan dibuat dalam sebuah tulisan. MoU menjadi sebuah dasar dalam melakukan pembuatan perjanjian kontrak dan MoU belum memiliki nilai yang standar dalam Kontrak hanya saja menjadi dasar pemikiran untuk menciptakan sebuah kontrak. Tahapan selanjutnya setelah memperoleh MoU para pihak dilanjutkan dengan teori layak tidaknya (feasibility study, due diligent) yang memiliki fungsi untuk menilai kelayakan dan kemungkinan terjadi usaha tersebut dimasa depan berdasarkan sudut pandang hukum, lingkungan, ekonomi, pemasaran, keuangan, sosial budaya, lingkungan, dan teknik. Teori kelayakan ini butuhkan dalam penilaian apakah transaksi para pihak patut untuk dilanjutkan. Setalah diuji maka apabila layak akan melanjutkan ke proses pembuatan perjanjian kontrak.

Perjanjian yang dibuat antara kedua pihak menimbulkan hak dan kewajiban antara para pihak. Penyewa memiliki hak untuk mendapatkan fasilitas ruko dan memiliki kewajiban untuk membayar biaya sewa yang sudah disepakati, sedangkan hak dan kewajiban yang menyewakan ialah berhak mendapatkan pembayaran dari penyewa dan memiliki kewajiban untuk menyerahkan ruko tersebut untuk dipergunakan oleh penyewa. Jika dikemudian hari terjadi keteledoran antara salah satu pihak yang berjanji maka harus mengganti rugi dan bertanggungjawab atas wanprestasinya (Prodjodikoro, 2011).

\section{SIMPULAN DAN SARAN}

\section{Simpulan}

Berdasarkan hasil analisis data dapat disimpulkan bahwa kegiatan sewa menyewa ruko dapat dikategorikan kerjasama saling menguntungkan satu sama lain disisi penyewa mendapatkan fasilitas guna membangun usaha sekaligus orang yang menyewakan mendapat pemasukan atau upah dari ruko miliknya sesuai kesepakatan antara para pihak. Untuk kepastian kesepakatan kedua pihak harus membuat perjanjian yang di buat sesuai kesepakatan bersama penyewa bertanggung jawab penuh atas kondisi ruko yang disewanya sedangkan pihak yang menyewakan menjamin keamanan ketentraman penyewa selama menempati ruko tersebut., yang kedua Perjanjian sewa menyewa tentu semata-mata melupakan aspek hukum, sanksi atau akibat hukum pasti tercantum dalam perjanjian yang telah disepakati sesuai aturan pemerintah. Selama pihak yang menyewakan dan pihak penyewa melakukan hak dan kewajiban dengan baik tanpa pelanggaran hukum maka perjanjian sewa menyewa akan berjalan sesuai keinginan kedua belah pihak namun tidak semua perjanjian berjalan mulus semisal akibat bangkrut usaha orang yang menyewa lalu meninggalkan ruko tanpa ada kejelasan kepada pihak menyewakan maka terjadi wanprestasi atau ingkar janji dapat dikenakan hukuman pidana.

\section{Saran}

Adapun yang disarankan peneliti adalah diharapkan kepada pihak yang melakukan perjanjian sebaiknya didiskusikan terlebih dahulu isi dari surat perjanjian yang akan di buat guna menghindari kejadian yang tidak diinginkan seperti terjadi wanprestasi akibat tidak sepakatnya perjanjian antara kedua belah pihak, yang kedua Bagi masyarakat dalam melakukan atau membuat suatu perjanjian agar lebih menelaah dan meneliti isi dari surat peranjian sebelum ditandatangani. Terjadi wanprestasi 
bukan hanya karena salah satu pihak tidak setuju dengan isi perjanjian yang dibuat melainkan ketidak telitian baik dari pihak penyewa ataupun yang menyewakan tentang isi perjanjian sewa menyewa. Terlebih dahulu mempelajari arti serta syarat-syarat perjanjian, menjadi individu yang cerdas dalam melakukan perjanjian membuat sewa menyewa terjalin dengan baik. Karena jika terjadi wanprestasi akan dikenakan hukuman pidana.

\section{DAFTAR PUSTAKA}

Ahmad, B. (2008). Metode Penelitian Hukum. Pustakasetia.

Hamsah, A. (1986). Perlindungan Terhadap Hak-hak Asasi Manusia. Bina cipta.

Kondo, C. (2013). Tanggung Jawab Hukum dalam Perjanjian Sewa Menyewa Rumah Toko (Ruko). 1(3), 145154.

Prodjodikoro, W. (2011). Asas-Asas Hukum Perjanjian. Bale Bandungg.

R. Setiawan. (1987). Pokok-Pokok Hukum Perikatan. PT. Bina Cipta.

Richards, J. C., \& Schmidt, R. (2010). Longman Dictionary of Language Teaching \& Applied Linguistics. In Longman Dictionary.

Salim, E. (1979). Lingkungan Hidup dan Pembangunan. Mutiara Sumber Widya.

Slamet, S. R. (2013). Tuntutan Ganti Rugi dalam Perbuatan Melawan Hukum: Suatu Perbandingan dengan Wanprestasi. Lex Jurnalica (Journal of Law), 10(2), 107-120.

Waluyo, B. (2002). Penelitian Hukum Praktek. Sinar Grafika. 